DOI https://doi.org/10.30525/978-9934-588-80-8-1.2

\title{
КОМУНІКАТИВНА КОМПЕТЕНТНІСТЬ ТА СТРЕСОСТІЙКІСТЬ ЯК СКЛАДОВІ ПРОФЕСІЙНОЇ КОМПЕТЕНТНОСТІ МАЙБУТНІХ ЛІКАРІВ
}

\author{
Астахов B. М. \\ доктор медичних наук, професор, \\ завідувач кафедри акушерства та гінекології \\ Донеиький національний медичний університет \\ м. Краматорськ, Украӥна \\ Бацилсва О. В. \\ доктор психологічних наук, професор, \\ професор кафедри психологіi \\ Донечький начіональний університет імені Василя Стуса \\ м. Вінниця, Україна \\ Пузь I. В. \\ кандидат психологічних наук, дочент, \\ доиент кафедри психологіi \\ Донечький нащіональний університет імені Василя Стуса \\ м. Вінниця, Украӥна
}

Загальновідомим є той факт, що професійна лікарська діяльність визначається наявністю різноманітних складних ситуацій, ефективне вирішення яких вимагає від фахівців надання невідкладної кваліфікованої допомоги, що має супроводжуватися вибором оптимального способу спілкування та взаємодії як з колегами, так і безпосередньо 3 пацієнтами та їх рідними. У зв'язку з цим особливого значення набуває сформованість у лікарів високого рівня комунікативної компетентності, оскільки саме володіння мистецтвом спілкування виступає, по-перше, необхідною умовою успішного впливу на особистість хворої людини; по-друге, одним із дієвих засобів профілактики та лікування різного роду захворювань; по-трете, основою ефективної групової лікарської співпраці під час діагностичного та лікувального процесів [1]. Слід також зазначити, що комунікативна компетентність лікаря по значущості для клінічної практики знаходиться на одному рівні з такими професійними компетенціями фахівців медичної галузі, як базові наукові знання, клінічне мислення, практичні вміння та навички [2]. 
Будучи складним багатоаспектним утворенням, комунікативна компетентність особистості виявляється у комунікативних знаннях, вміннях та якостях, необхідних не тільки для передачі та прийняття різного роду інформації, але й для взаємодії з іншими людьми, для виконання різного роду соціальних ролей в групах та колективах [4]. Комунікативна компетентність лікаря передбачає розвинені вміння встановлювати та підтримувати необхідні контакти, розуміти невербальні прояви співрозмовника під час спілкування, конструктивно вирішувати різного роду труднощі, які можуть виникати під час взаємодії з пацієнтами та їх рідними, з колегами.

Важливим моментом у роботі лікаря $\epsilon$ вибір тактики індивідуального спілкування з кожним пацієнтом, яка має відповідати не тільки психоемоційному стану хворої людини, але і ії індивідуальнопсихологічним особливостям загалом. На думку більшості дослідників, саме позитивний контакт лікаря 3 пацієнтом значно підвищує ефективність лікувального процесу та загальний рівень задоволеності пацієнта від наданої медичної допомоги [2; 5]. Комунікативна компетентність лікаря сприяє встановленню довірливих стосунків 3 пацієнтами, що, безумовно, буде мати позитивне значення у лікуванні хвороби [1].

У структурі комунікативної компетентності лікаря прийнято виокремлювати мотиваційний, когнітивний, емоційний, поведінковий та особистісний компоненти. Так, мотиваційний компонент утворюють індивідуальні потреби особистості у позитивних контактах, iї цінності, пов'язані зі спілкуванням та взаємодією 3 оточуючими. До когнітивного компоненту відносяться рефлексивні, аналітичні та оцінні здібності, а також знання, що стосуються особливостей міжособистісного спілкування та взаємодії. Емоційний компонент виявляється у здібності адекватно сприймати та надавати об'єктивну оцінку партнерам по комунікації, розуміти їх психоемоційний стан, демонструвати емпатію. Поведінковий компонент визначає індивідуальну систему оптимальних моделей міжособистісної взаємодії, а також здатність до суб'єктивного контролю власної поведінки під час комунікації. Особистісний компонент включає певну сукупність індивідуальних якостей, провідними серед яких є висока мотивація на успішну комунікацію, емоційна стабільність, афіліація, толерантність.

Слід зазначити, що комунікативна компетентність виступає як однією із важливих складових професійної компетентності лікарів, так і важливою передумовою для успішної професійної адаптації молодих фахівців. Сучасна професійна підготовка майбутніх лікарів передбачає не тільки формування необхідних професійних знань, але й розвиток 14 
професійно значущих якостей особистості, серед яких особливого значення набуває саме комунікативна компетентність, що забезпечує ефективне включення майбутніх лікарів як в освітнє, але й подальше у професійне середовище.

Професійна діяльність сучасних лікарів характеризується зростанням інтенсифікації праці, підвищенням вимог до професійної відповідності і стабільності людини при здійсненні різного роду лікувально-діагностичних завдань, що передбачає їх готовність i здатність долати стани напруження, повсякденні стресові ситуації, які зумовлені, перш за все, особливими умовами здійснення лікарської діяльності, серед яких можна виокремити: високе інтелектуальне навантаження; психоемоційне напруження; надзвичайний рівень відповідальності; необхідність примати рішення в умовах дефіциту часу та інформації; постійне спілкування з великою кількістю людей, які відрізняються за типом темпераменту, домінуючим емоційним станом, рівнем освіти, станом здоров'я [1]. Враховуючи вищевикладене слід зауважити, що професія лікаря є особливо вразливою до дії різного роду стресових чинників, тому вимагає від фахівців постійної актуалізації когнітивних, емоційних, рефлексивних та інших можливостей та ресурсів їхньої особистості. Встановлено, що у більшості випадків, коли професійні умови і вимоги до роботи перевершують внутрішні та зовнішні ресурси, організм людини відповідає на них закономірною реакцією, що знаходить своє негативне відображення не тільки на стані професійного здоров'я, але й здоров'я особистості в цілому. Отже, стає зрозумілим, що, поряд з комунікативною компетентністю, важливою складовою професійної компетентності майбутнього лікаря виступає стресостійкість, яка може бути визначена як властивість особистості, що забезпечує гармонійне співвідношення між усіма компонентами психічної діяльності в емоціогенній ситуації, і тим самим, сприяє успішному виконанню професійної діяльності [3].

Аналіз наукової літератури показав, що визначення сутності стресостійкості можна розглядати з двох основних аспектів: по-перше, як характеристику успішності діяльності та здатності підтримувати оптимальну працездатність і ефективність діяльності в напружених ситуаціях; по-друге, як властивість, що впливає на результат діяльності (успішність-неуспішність) і характеристику, що забезпечує рівновагу особистості як системи; тобто стресостійкість розглядається як діяльнісний і особистісний показник, що визначає здатність людини протистояти впливу стресових чинників та зберігати ефективну поведінку в стресових ситуаціях, активно перетворюючи їх або 
пристосовуючись до них без шкоди для здоров'я і якості діяльності, що виконується [3]. На нашу думку, саме високий рівень стресостійкості у лікарів сприятиме успішному виконанню професійних обов'язків в напружених умовах, у тому числі підтриманню ефективного спілкування та взаємодії як з колегами, так і з пацієнтами та їх рідними.

Узагальнюючи вищевикладене стає зрозумілим, що особливої актуальності та значення для майбутніх лікарів набувають питання, пов'язані із формуванням низки практичних вмінь та навичок, зокрема вміти протистояти дії різного роду стресогенних чинників, встановлювати i підтримувати різного роду контакти, отримувати i надавати інформацію, використовуючи при цьому ефективні техніки та прийоми спілкування, вербальні та невербальні канали комунікації, а також успішно працювати в команді фахівців.

Враховуючи значення комунікативної компетентності та стресостійкості у професії лікаря, на нашу думку, а також думку інших фахівців, одним із найбільш ефективних засобів для формування та розвитку окреслених професійно важливих якостей виступає впровадження у процес підготовки майбутніх лікарів проведення низки соціально-психологічного тренінгів, що мають бути спрямовані на формування навичок ефективного спілкування та взаємодії, а також навичок психічної саморегуляції, що сприятиме підвищенню рівня стресостійкості, безумовно, матиме позитивний вплив на подальше особистісне та професійне становлення фахівців.

\section{Література:}

1. Бацилєва О. В., Астахов В. М., Пузь І. В. Роль комунікативної компетентності у професійній діяльності лікарів. Медична симуляція погляд у майбутнє (впровадження інноваційних технологій у Вищу медичну освіту України) (для лікарів, науковців та молодих вчених) : наук.-практ. конференція з міжнародною участю. Вінниця 08.02.2019: тези доп. - Вінниця : ВНМУ імені І. М. Пірогова, 2019. С. 5-6.

2. Гуменна I. Р. Комунікативна компетентність як одна із складових професійної культури майбутніх лікарів. Науковий вісник Ужсгородського національного університету. Серія: Педагогіка, Соціальна робота. Вип. 29. 2013. С. 42-45. http://nbuv.gov.ua/UJRN/ Nvuuped_2013_29_14

3. Дубчак Г. М. Психологічні основи професійної стресостійкості майбутніх фахівців : [монографія]. К. : Талком, 2017. 321 с.

4. Пузь I. В., Астахов В. М. Комунікативна компетентність як передумова успішного професійного становлення сучасних фахівців. Наука, освіта, суспільство: реалї̈, виклики, перспективи: зб. матеріалів 16 
міжнародної наук.-практ. конференції (16-17 травня 2019, м. Вінниця). Вінниця: ТОВ «Твори», 2019. Т. 1. С. 195-197.

5. Чижкова М. Б. Комуникативная компетентность врача и ее формирование в представлениях ординаторов: к постановке проблемы. Современные проблемы науки и образования. 2020. № 2. URL: http://science-education.ru/ru/article/view?id=29727

DOI https://doi.org/10.30525/978-9934-588-80-8-1.3

\title{
МОЖЛИВОСТІ ДЛЯ ФОРМУВАННЯ МОЛОДОГО НАУКОВЦЯ ПІД ЧАС НАВЧАННЯ В УНІВЕРСИТЕТІ
}

\author{
Басюга I. O. \\ кандидат медичних наук, \\ доцент кафедри акушерства і гінекології імені І. Д. Ланового \\ Івано-Франківський начіональний медичний університет \\ Костіцька I. O. \\ доктор медичних наук, \\ професор кафедри ендокринології \\ Івано-Франківський начіональний медичний університет \\ Матвійків Н. I. \\ кандидат медичних наук, \\ асистент кафедри акушерства і гінекології ПО \\ Івано-Франківський начіональний медичний університет \\ м. Івано-Франківськ, Украӥна
}

Основні завдання та вимоги щодо професійної діяльності сучасних фахівців $є$ достатньо високі, вимагають від викладача забезпечити майбутнього фахівця базовою інформацією, розвинути у нього навички та уміння для розв'язання конкретних завдань. Впровадження та застосування інформаційних технологій (IT) дозволяе підвищити якість освіти, підібрати індивідуальні засоби засвоєння знань шляхом самостійної роботи, формування вміння самостійно здобувати знання $\mathrm{i}$ вести дослідницьку діяльність[1, 2 с. 132].

Для студентів, які бажають отримати глибші знання, детально вивчити окремі нозоології, з можливістю проведення самостійного науково-дослідного вивчення, на кафедрах університету функціонують студентські наукові гуртки. Активна участь студентів в науково- 